\title{
Antimicrobial peptide LL-37 promotes the viability and invasion of skin squamous cell carcinoma by upregulating YB-1
}

\author{
WEI WANG ${ }^{1}$, YAN ZHENG ${ }^{1}$, JINJING JIA $^{1}$, CHANGJI LI $^{1}$, QIQI DUAN ${ }^{1}$, \\ RUILIAN LI ${ }^{1}$, XIN WANG ${ }^{1}$, YONGPING SHAO ${ }^{2,3}$, CAIFENG CHEN $^{1}$ and HULING YAN ${ }^{1}$ \\ ${ }^{1}$ Department of Dermatology, The Second Affiliated Hospital of Xi'an Jiaotong University; \\ ${ }^{2}$ Key Laboratory of Biomedical Information Engineering of the Ministry of Education, School of Life Science and Technology \\ and ${ }^{3}$ Frontier Institute of Science and Technology, Xi'an Jiaotong University, Xi'an, Shaanxi 710004, P.R. China
}

Received October 7, 2015; Accepted January 26, 2017

DOI: 10.3892/etm.2017.4546

\begin{abstract}
Antimicrobial peptide LL-37 serves a function in the host defense against microbial invasion, and also regulates cell proliferation, immune activity and angiogenesis. Previous studies have reported that LL-37 participates in the development of numerous tumour types, such as ovarian cancer, lung cancer, melanoma and breast cancer. However, the function of LL-37 in the development of skin squamous cell carcinoma (SCC) has not yet been fully elucidated. The aim of the current study was to investigate how LL-37 promotes the expression of Y-box binding protein 1 (YB-1) in SCC. Short interfering RNA (siRNA) was used to inhibit the expression of YB-1, and in vitro MTT and Transwell migration assays were used to evaluate the effect of reduced YB-1 on the viability and invasion of A431 cells. A431 cells were stimulated with LL-37, and quantitative polymerase chain reaction, immunofluorescence and western blot analyses were used to detect changes in YB-1 expression. Mitogen-activated protein kinase kinase, mitogen-activated protein kinase and nuclear factor (NF) $-\mathrm{kB}$ signaling pathway inhibitors were also used to evaluate the mechanism of LL-37-induced YB-1 protein expression. It was found that YB-1 expression was increased in SCC tissue compared with normal tissue. Inhibiting YB-1 expression using siRNA significantly reduced the viability and suppressed the invasion of tumour cells ( $\mathrm{P}<0.05$ for both). LL-37 treatment at $0.05 \mu \mathrm{g} / \mathrm{ml}$ for 24 or $48 \mathrm{~h}$ significantly promoted YB-1 protein expression $(\mathrm{P}<0.05)$, and this was dependent on the NF- $\kappa B$ signaling pathway. In conclusion, the current study demonstrated that by upregulating the expression of YB-1, LL-37 can promote the occurrence and development of SCC, and this process involves the NF- $\mathrm{kB}$ signaling pathway.
\end{abstract}

Correspondence to: Dr Yan Zheng, Department of Dermatology, The Second Affiliated Hospital of Xi'an Jiaotong University, 157 Xiwu Road, Xi'an, Shaanxi 710004, P.R. China

E-mail: zenyan66@126.com

Key words: LL-37, squamous cell carcinoma, Y-box binding protein 1 , epidermis growth factor receptor, nuclear factor- $\mathrm{kB}$

\section{Introduction}

Squamous cell carcinoma (SCC), sourced from epithelial keratinocytes, accounts for $20 \%$ of non-melanoma skin cancer cases (1). It usually develops from certain skin or precancerous lesions. Currently, there are $\sim 1,000,000$ new cases each year, and the mortality rate is currently increasing $(2,3)$.

Y-box binding protein 1 (YB-1) has a cold shock domain and serves multiple functions in cells through binding directly or indirectly to target gene sequences to regulate gene transcription and translation $(4,5)$. YB-1 is expressed in the nucleus and cytoplasm of cells $(6,7)$. Previous studies have reported that YB-1 upregulation is related to the growth and resistance of tumour cells to chemotherapy in multiple tumour cell types. Therefore, it is known as a cancer prognosis marker $(8,9)$. Its overexpression is an indication of increased proliferation and invasion of tumour cells (8-10). In breast cancer tissues, it has previously been demonstrated that YB-1 upregulation is associated with epidermis growth factor receptor (EGFR) and human epidermal growth factor receptor-2 (HER-2) upregulation. HER-2 also regulates the nuclear translocation of YB-1 $(10,11)$. Furthermore, inhibiting the expression of YB-1 in melanoma cells significantly increased their sensitivity to chemotherapy, and this process was related to regulation of the phosphoinositide 3-kinase/Akt signaling pathway $(10,11)$. These results suggest that YB-1 expression is closely related to tumour development and progression.

LL-37 is a member of the cathelicidin family and is a cationic peptide composed of 37 amino acid residues in the human body. It is a key component of the biological innate immune system and is mediated by neutrophils (12-14). In addition, LL-37 serves a key function in angiogenesis and cell proliferation $(13,15)$. Previous studies have indicated that LL-37 is upregulated in a variety of solid tumours, and is also involved in promoting the progression mechanisms of numerous tumour types, such as the proliferation, migration and invasion of ovarian cancer, lung cancer, breast cancer and melanoma tumour cells (16-21). Moreover, previous studies have reported that these characteristics may be associated with EGFR, formyl peptide receptor-like 1 (FPRL1) and the insulin-like growth factor 1 receptor $(14,22-24)$. However, the mechanisms underlying the effects of LL-37 on the viability 
and invasion of SCC cells, and the relationship between LL-37 and YB-1, are not yet fully understood.

The current study aimed to investigate the effect of LL-37 on YB-1 expression and the viability and invasion of SCC cells. The results indicated that LL-37 promoted the viability and invasion of SCC cells through increasing YB-1 expression, and this process involved the nuclear factor $(\mathrm{NF})-\kappa \mathrm{B}$ signaling pathway.

\section{Materials and methods}

Tissue collection. Fresh SCC and adjacent normal tissues were obtained from 20 patients (12 males and 8 females; age range, 32-58 years) who underwent skin biopsies between 2013 and 2014 at the Department of Dermatologic Surgery of The Second Affiliated Hospital of the Medical College of Xi'an Jiaotong University (Xi'an, China). All SCC cases were clinically and pathologically verified. Standard protocols established by the Hospital's Protection of Human Subjects Committee were followed in this study and informed consent was provided from all patients in the present study. SCC lesions were obtained from the center of SCC tissues. The uninvolved tissues surrounding the SCC were obtained from the normal tissues surrounding the SCC tissues. Normal skin tissues were obtained from cosmetic surgeries.

Cell culture. A human squamous cell carcinoma cell line (A431) (Shanghai Xiang Shi Biotechnology, Co.,Ltd., Shanghai, China) was cultured in F12 medium (Gibco; Thermo Fisher Scientific, Inc., Waltham, MA, USA) supplemented with $10 \%$ fetal bovine serum (FBS, Gibco; Thermo Fisher Scientific, Inc.), 100 U/ml penicillin and $100 \mu \mathrm{g} / \mathrm{ml}$ streptomycin (both Sigma-Aldrich; Merck KGaA, Darmstadt, Germany). Cells were cultured at $37^{\circ} \mathrm{C}$ with $5 \% \mathrm{CO}_{2}$.

Immunohistochemistry. Normal skin tissues, uninvolved tissues surrounding the SCC and SCC lesions were analyzed by immunohistochemistry. Paraffin-embedded tissue sections (4- $\mu \mathrm{m}$ thick) were dewaxed in xylene and re-hydrated in gradient alcohol, then incubated with rabbit anti-human YB-1 monoclonal antibody (1:50; ab76149; Abcam, Cambridge, UK) and the slides were placed in a humid environment at $4^{\circ} \mathrm{C}$ overnight before being incubated with goat anti-rabbit antibody $\left(1: 1,000\right.$; ab6721; Abcam) at $37^{\circ} \mathrm{C}$ for $30 \mathrm{~min}$. Next, the sections were stained with 3,3'-diaminobenzidine (Sigma-Aldrich; Merck KGaA) and observed using an optical microscope (magnification, x200). Normal skin tissue samples were used as the negative controls.

Inhibiting YB-1 expression using short interfering $R N A$ ( siRNA). The following siRNA oligonucleotide sequences were synthesized by Shanghai GenePharma Co., Ltd. (Shanghai, China) in order to select the most effective one: YB-1 siRNA 1: 5'-GCAGACCGUAACCAUUAUATT-3' (sense) and 5'-UAU AAUGGUUACGGUCUGCTT-3' (antisense); YB-1 siRNA 2: 5'-CGGCAAUGAAGAAGAUAAATT-3' (sense) and 5'-UUUAUCUUCUUCAUUGCCGTT-3' (antisense); YB-1 siRNA 3: 5'-CUGCCAUAAAGAAGAAUAATT-3' (sense) and 5'-UUAUUCUUCUUUAUGGCAGTT-3' (antisense). The negative control duplexes of siRNA were random sequences and did not target any known mammalian gene according to GenBank searches (National Center for Biotechnology Information, Bethesda, MD, USA). A431 cells were transfected with siRNAs according to the recommended procedures for Lipofectamine 2000 transfection reagent (Invitrogen, Carlsbad, CA). A431 cells were seeded in 6-well plates at a density of $10^{5}$ cells/well. When the fusion reached $70-80 \%$, the cells were treated with serum-free F12 medium, according to the manufacturer's protocols. The YB-1 inhibition rate was analyzed using western blot analysis (described below).

Viability and invasion assay of siRNA-transfected cells. Transfected cells, which were transfected with siRNA1, the most effective siRNA of the 3 siRNA sequences, were seeded at a density of $3 \times 10^{3}$ cells/well and cultured in serum-free F12 medium for $24 \mathrm{~h}$. MTT (5 mg/ml; $10 \mu \mathrm{l}$; Sigma-Aldrich; Merck $\mathrm{KGaA}$ ) was added to each well and left to incubate at $37^{\circ} \mathrm{C}$ for $4 \mathrm{~h}$. Subsequently, $150 \mu \mathrm{l}$ dimethyl sulfoxide (DMSO; Sigma-Aldrich; Merck KGaA) was added and the absorbance was measured at $490 \mathrm{~nm}$ using a microplate reader (Bio-Rad Laboratories, Inc., Hercules, CA, USA).

Cell invasion was evaluated using a polycarbonate membrane with a pore size of $8 \mu \mathrm{m}$ that was pre-coated with Matrigel (BD Biosciences, Franklin Lakes, NJ, USA) and Transwell chambers (Costar; Corning, Inc., Corning NY, USA). The transfected cells were starved without serum for $12 \mathrm{~h}$, then re-suspended in serum-free medium at a density of $2.5 \times 10^{5}$ cells $/ \mathrm{ml}$. A $200-\mu 1$ cell suspension was added to each Transwell chamber and $500 \mu \mathrm{l}$ culture medium with $10 \%$ FBS was added to the lower chamber. After culturing for $24 \mathrm{~h}$ at $37^{\circ} \mathrm{C}$, the cells that invaded the lower chamber were stained with a staining solution $(0.1 \%$ crystal violet ethanol). Three representative fields were randomly selected and the average number of invaded cells was calculated.

Total RNA extraction and quantitative polymerase chain reaction $(q P C R)$. TRIzol reagent (Sigma-Aldrich; Merck $\mathrm{KGaA}$ ) was used to extract total RNA from cells. Total RNA $(3 \mu \mathrm{g})$ was then reverse transcribed to cDNA in a total volume of $20 \mu \mathrm{l}$ using a reverse transcription reaction kit (Promega Corporation, Madison, WI, USA) according to the manufacturer's instructions. Then, qPCR was performed using an Mx 3000P qPCR system (Applied Biosystems; Thermo Fisher Scientific, Inc.), according to the manufacturer's instructions. SYBR Premix Ex Taq II (Takara Biotechnology Co., Ltd., Dalian, China) was used as a DNA-specific fluorescent dye. PCR was performed for 50 cycles of $95^{\circ} \mathrm{C}$ for $10 \mathrm{sec}$ and $60^{\circ} \mathrm{C}$ for $30 \mathrm{sec}$. Primer sequences for detection of mRNA expression were synthesized as follows: YB-1 specific primers, 5-CAG AATAGTGAGAGTGGGG-3 (forward) and 5-ATGTAGTAA GGTGGGAACC-3 (reverse); human $\beta$-actin primers, 5-TTC CATATCGTCCCAGTTGGT-3 (forward) and 5-CCAGGG CGTTATGGTAGGCA-3 (reverse). The YB-1 transcriptional level was normalized against the transcriptional level of $\beta$-actin. All values are from the results of at least three independent experiments. Relative mRNA expression levels were calculated using the $2^{-\Delta \Delta \mathrm{Cq}}$ method (25).

Immunofluorescence staining. After placing a monolayer of cells on the climbing film,LL-37 (Sigma-Aldrich; Merck KGaA) 
of the appropriate concentration $(0,0.05,0.5$ or $5 \mu \mathrm{g} / \mathrm{ml})$ was added for $48 \mathrm{~h}$. Then, the cells were fixed with $4 \%$ paraformaldehyde at room temperature for $10 \mathrm{~min}$, followed by treatment with $5 \%$ Triton X-100 for $15 \mathrm{~min}$ at room temperature. They were then sealed with $1 \%$ goat serum $(200 \mu \mathrm{l}$; Thermo Fisher Scientific, Inc.) at $37^{\circ} \mathrm{C}$ for $30 \mathrm{~min}$. Cells were incubated with a 1:50 diluted rabbit anti-human YB-1 monoclonal antibody overnight at $4^{\circ} \mathrm{C}$. Then, they were incubated with a fluorescein isothiocyanate-labeled goat anti-rabbit antibody $(1: 2,000)$ at $37^{\circ} \mathrm{C}$ for $1 \mathrm{~h}$. Finally, the cells were stained with DAPI for $1 \mathrm{~min}$ and the staining intensity was observed using a fluorescence inverted microscope (magnification, x400; Zeiss LSM 700; Zeiss AG, Oberkochen, Germany).

Protein extraction and western blot analysis. LL-37-stimulated cells were treated with 100-400 $\mu \mathrm{l}$ of a mixture comprising PBS, 5 mM EDTA, 0.5\% Triton X-100, 20 mM NaF, $1 \mathrm{mM}$ orthovanadate, $1 \mathrm{mM}$ pyrophosphate and protease inhibitors (0.1 mM phenylmethylsulfonyl fluoride, $10 \mu \mathrm{M}$ pepstatin $\mathrm{A}$, $10 \mu \mathrm{M}$ leupeptin, $25 \mu \mathrm{g} / \mathrm{ml}$ aprotinin) for $30 \mathrm{~min}$ at $4^{\circ} \mathrm{C}$, then the cell lysates were separated via centrifugation $(13,523 \mathrm{x} g$ at $4^{\circ} \mathrm{C}$ for $20 \mathrm{~min}$ ). Approximately $10 \mu \mathrm{g}$ of the protein isolates were separated with $10 \%$ SDS-PAGE and transferred to a polyvinylidene difluoride membrane. The membrane was blocked with $5 \%$ non-fat milk and $0.1 \%$ PBS with Tween-20 at room temperature for $2 \mathrm{~h}$ and then treated with rabbit anti-human monoclonal antibody YB-1 (1:500) at $4^{\circ} \mathrm{C}$ overnight. Subsequently, the membrane was hybridized with goat anti-rabbit secondary antibody $(1: 5,000)$ for $1 \mathrm{~h}$. The results were detected using an enhanced chemiluminescence kit (EMD Millipore, Billerica, MA, USA). The sample protein expression was presented relative to $\beta$-actin expression.

Analysis of the signal transduction pathways of the $Y B-1$ induction by $L L-37$. SCC cells were seeded at $10^{5}$ cells/well and treated with the mitogen-activated protein kinase kinase (MEK) inhibitor, PD98059 (10 $\mu \mathrm{M}$; Abcam), the p38/mitogen-activated protein kinase (MAPK) inhibitor, SB203580 (10 $\mu \mathrm{M}$; Abcam) or the NF- $\mathrm{B}$ inhibitor, ammonium pyrrolidinedithiocarbamate (PDTC; $1 \mu \mathrm{M}$; Abcam) for $30 \mathrm{~min}$. Then, $0.5 \mu \mathrm{M} \mathrm{LL}-37$ was added and incubated at $37^{\circ} \mathrm{C}$ for $24 \mathrm{~h}$. The protein was then extracted for western blot analysis (described above).

Cell viability assay after LL-37 stimulation. The cells were seeded at a density of $3 \times 10^{3}$ cells/well with serum-free medium for $24 \mathrm{~h}$. In order to evaluate the effect of dosage, LL-37 at concentrations of $0,0.05,0.5$ or $5 \mu \mathrm{g} / \mathrm{ml}$ was used to stimulate the cells for $24 \mathrm{~h}$. In order to evaluate the effect of treatment duration, $0.5 \mu \mathrm{g} / \mathrm{ml} \mathrm{LL}-37$ was used to stimulate the cells for 0 , 24,48 or $72 \mathrm{~h}$. Then, MTT $(5 \mathrm{mg} / \mathrm{ml} ; 10 \mu \mathrm{l})$ was added and the cells were cultured for $4 \mathrm{~h}$ at $37^{\circ} \mathrm{C}$. DMSO $(150 \mu \mathrm{l})$ was added for $10 \mathrm{~min}$. The absorbance was measured at $490 \mathrm{~nm}$ using a microplate reader.

Cell migration and invasion assay after LL-37 stimulation. The migration assay was conducted using a polycarbonate membrane with a pore size of $8 \mu \mathrm{m}$ and Transwell chambers (EMD Millipore, Billerica, MA, USA). The cells $\left(2.5 \times 10^{5}\right.$ cells $\left./ \mathrm{ml}\right)$ were suspended in serum-free F12 culture medium. A $200 \mu \mathrm{l}$ cell suspension was added to each Transwell

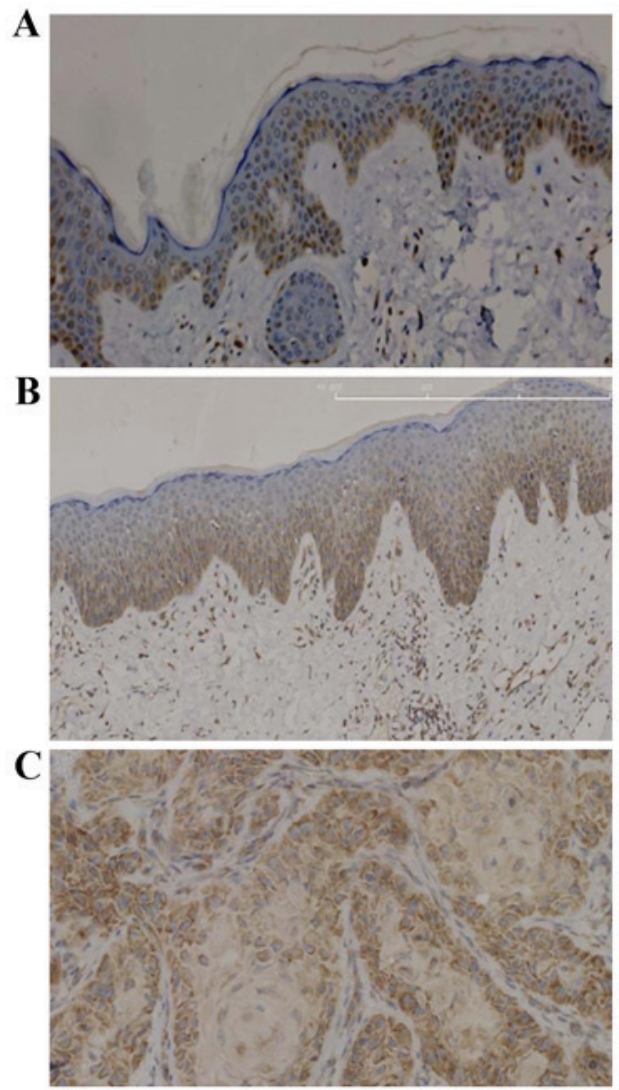

Figure 1. Immunohistochemical analysis of YB-1 expression in (A) normal skin, (B) tissue surrounding the SCC and (C) SCC. YB-1 expression is stronger in SCC than in normal or surrounding skin tissue. Brown stain indicates YB-1 expression. Magnification, x200. YB-1, Y-box binding protein 1; SCC, squamous cell carcinoma.

chamber and $500 \mu \mathrm{l}$ culture medium with $10 \%$ FBS was added to the lower chamber. In the upper chamber, a specific concentration of $0,0.05,0.05$ or $5 \mu \mathrm{g} / \mathrm{ml} \mathrm{LL}-37$ was added. After $24 \mathrm{~h}$, the residual cells on the surface were gently wiped out using a cotton swab. The cells that invaded the lower chamber were stained with staining solution $(0.1 \%$ crystal violet ethanol) and observed under a light microscope (magnification, x200). Three representative fields were randomly selected and the average number of invaded cells was calculated. With the pre-coated Matrigel (BD Biosciences) Transwell chambers, the invasion experiment was performed similar to the migration assay.

Statistical analysis. Statistical analysis was conducted using SPSS 17.0 software (SPSS, Inc., Chicago, IL, USA). All data are presented as the mean \pm standard deviation. Comparisons between two groups were analysed using a two-tailed t-test. Comparisons among three or more groups were evaluated using analysis of variance and Fisher's least significant difference test. $\mathrm{P}<0.05$ was considered to indicate a statistically significant difference.

\section{Results}

$Y B-1$ is upregulated in SCC. In normal skin tissues and uninvolved skin tissues adjacent to SCC, YB-1 protein was strongly expressed in the basal layer and weakly expressed in the lower layers of the stratum spinosum (Fig. 1A and B). However, in 
A Without
treatment Mock siRNA1 siRNA2 siRNA3
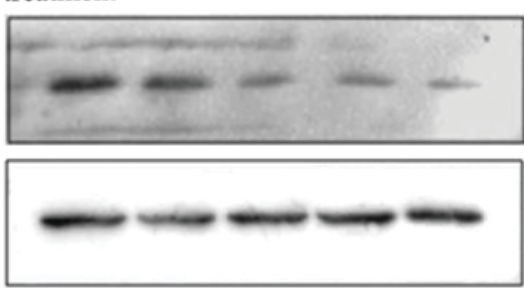

YB-1

$(50 \mathrm{kDa})$

$\beta$-actin

$(43 \mathrm{kDa})$

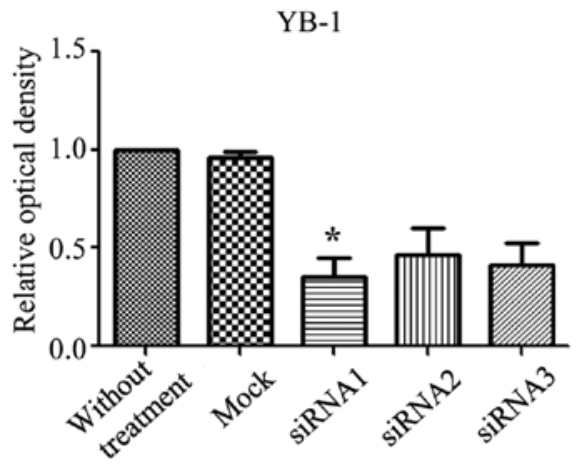

B

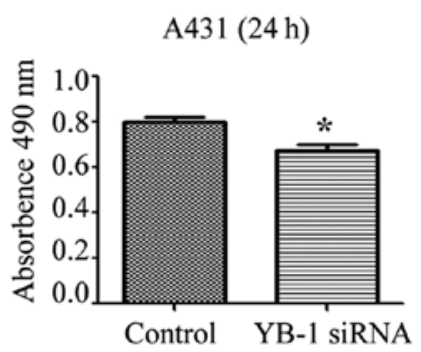

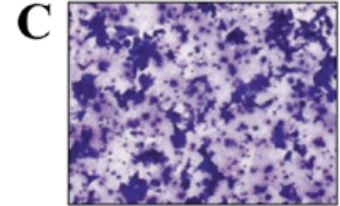

Control

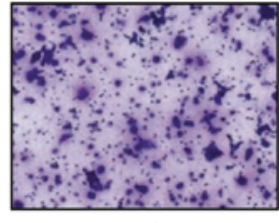

YB-1 siRNA

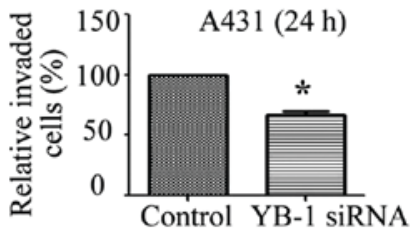

D

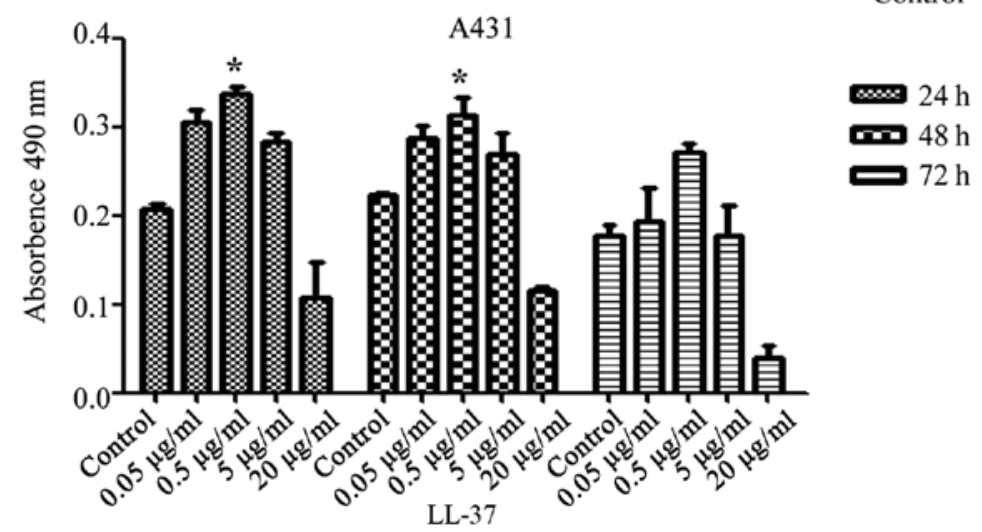

Figure 2. Effects of YB-1 siRNA inhibition and LL-37 stimulation in squamous cell carcinoma tissues and cells. (A) Western blot analysis of YB-1 and $\beta$-actin expression A431 cells after treatment with YB-1 siRNA (1-3) or control siRNA. (B) MTT assay to evaluate effect of YB-1 siRNA on A431 cell viability. (C) Transwell assay to evaluate the effect of YB-1 siRNA on A431 cell invasion. (D) MTT assay to evaluate effect of LL-37 treatment $(0,0.05,0.5,5$ or $20 \mu \mathrm{g} / \mathrm{ml}$ ) for 24,48 or $72 \mathrm{~h}$ on cell viability. The results from three independent experiments are shown as the mean \pm standard deviation, $\mathrm{n}=5$ samples in each group. " $\mathrm{P}<0.05$ vs. control. YB-1, Y-box binding protein 1; siRNA, short interfering RNA.

SCC tissues, YB-1 was strongly expressed in nearly all tumour cells (Fig. 1C).

$Y B-1$ siRNA inhibits the protein levels of YB-1 and reduces the viability and invasion of SCC cells. Total protein was extracted from siRNA-transfected cells and analysed by western blot analysis. Compared with the control group, the YB-1 siRNA 1 significantly inhibited the expression of YB-1 ( $\mathrm{P}<0.05$; Fig. 2A). Based on this result, the expression of $\mathrm{YB}-1$ in A431 cells was then inhibited by transfection with YB-1 siRNA 1. Compared with the control group, the viability of the cells significantly decreased $(\mathrm{P}<0.05$; Fig. $2 \mathrm{~B})$, which indicated that the viability of SCC cells was at least partly dependent on YB-1. The invasion ability of the A431 cells was also evaluated. Compared with the control group, the proportion of invaded cells significantly decreased ( $\mathrm{P}<0.05$; Fig. $2 \mathrm{C}$ ), which suggested that the invasiveness of SCC cells was at least partly dependent on YB-1. Thus, the inhibition of YB-1 may reduce the viability and invasiveness of A431 cells.

Effect of LL-37 on the viability of SCC cells. A431 cells were stimulated with LL-37 $(0,0.05,0.5,5$ or $20 \mu \mathrm{g} / \mathrm{ml})$ and the effect on cell viability was observed at different time intervals ( 24,48 or $72 \mathrm{~h}$ ). Treatment with $0.5 \mu \mathrm{g} / \mathrm{ml}$ LL-37 significantly increased cell viability at both 24 and $48 \mathrm{~h}$ compared with the respective control groups ( $\mathrm{P}<0.05$ for both; Fig. 2D).

LL-37 promotes the migration and invasion of SCC cells. The effect of different LL-37 concentrations $(0,0.05,0.5$ or $5 \mu \mathrm{g} / \mathrm{ml}$ ) on the migration of A431 cells was investigated. Compared with the control group, $0.05 \mu \mathrm{g} / \mathrm{ml}$ LL-37 significantly increased the migration of A431 cells ( $\mathrm{P}<0.05$; Fig. 3A). Furthermore, the effect of different LL-37 concentrations $(0,0.05,0.5$ or $5 \mu \mathrm{g} / \mathrm{ml})$ on the invasiveness of A431 cells was 
A

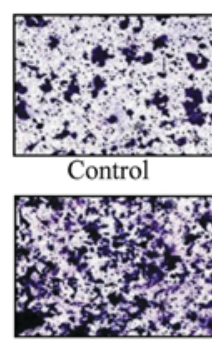

LL-37 $0.5 \mu \mathrm{g} / \mathrm{ml}$

B

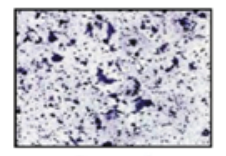

Control

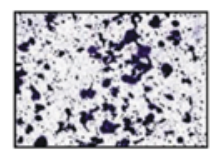

LL-37 $0.5 \mu \mathrm{g} / \mathrm{ml}$
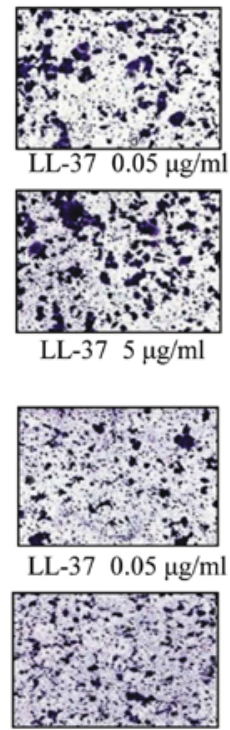

LL-37 $5 \mu \mathrm{g} / \mathrm{ml}$

C

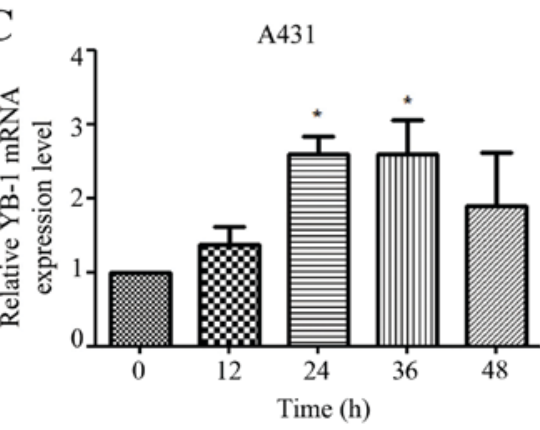

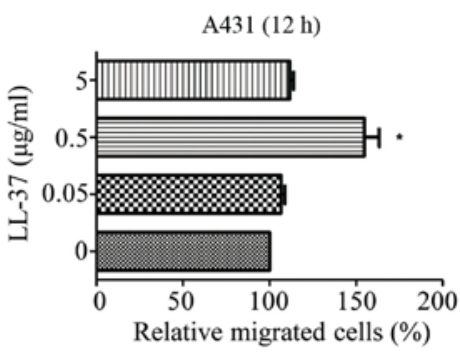
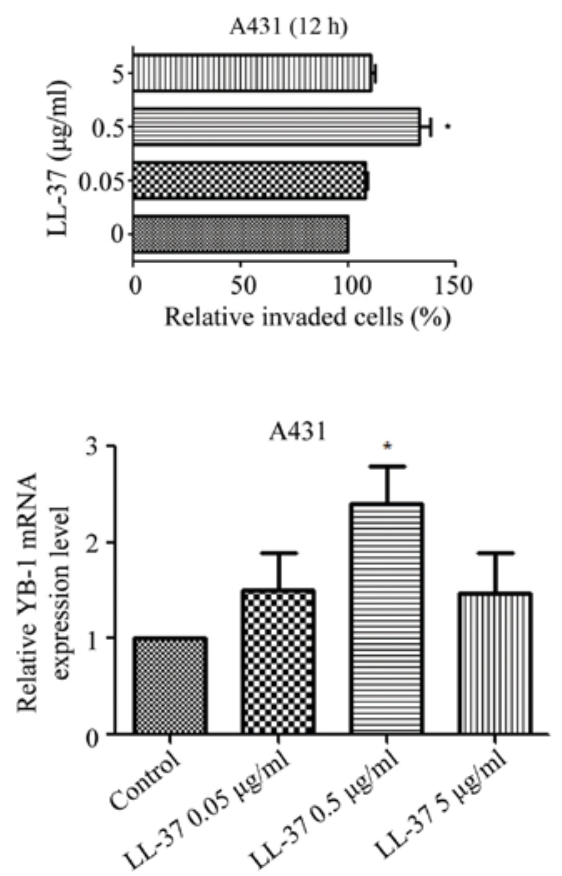

Figure 3. Effect of LL-37 treatment on migration, invasion and YB-1 mRNA expression in squamous cell carcinoma cells. (A) Effect of LL-37 treatment on migration in A431 cells. Serum-starved A431 cells were treated with LL-37 at $0.05,0.5$ or $5 \mu \mathrm{g} / \mathrm{ml}$ for $12 \mathrm{~h}$, and cell migration was analysed using a Transwell assay. (B) Effect of LL-37 treatment on invasion by A431 cells. Serum-starved A431 cells were treated with LL-37 at $0.05,0.5$ or $5 \mu \mathrm{g} / \mathrm{ml}$ for $24 \mathrm{~h}$, and the cell invasion was analysed using a Transwell assay. Magnification, x200. (C) Effect of LL-37 treatment on YB-1 mRNA expression in A431 cells. Time effect: A431 cells were stimulated with $0.5 \mu \mathrm{g} / \mathrm{ml}$ LL-37 for $0,12,24,36$ or $48 \mathrm{~h}$. Dose effect: A431 cells were stimulated with $0,0.05,0.5$ or $5 \mu \mathrm{g} / \mathrm{ml} \mathrm{LL}-37$ for $24 \mathrm{~h}$. YB-1 mRNA levels were determined by quantitative polymerase chain reaction. YB-1 mRNA expression is presented relative to $\beta$-actin mRNA expression. ${ }^{*} \mathrm{P}<0.05$ vs. control. YB-1, Y-box binding protein 1.

investigated. Compared with the control group, $0.05 \mu \mathrm{g} / \mathrm{ml}$ LL-37 significantly enhanced the invasiveness of A431 cells ( $\mathrm{P}<0.05$; Fig. 3B).

Effect of LL-37 on YB-1 mRNA expression in SCC cells. qPCR was used to evaluate the effect of LL-37 treatment at different concentrations $(0,0.05,0.5$ or $5 \mu \mathrm{g} / \mathrm{ml})$ and durations $(0,12,24,36$ or $48 \mathrm{~h})$ on the expression of YB-1 in SCC cells. Compared with the control group, stimulation of A431 cells with LL-37 for 24 or $36 \mathrm{~h}$ significantly increased the mRNA expression of YB-1 ( $\mathrm{P}<0.05$; Fig. 3C). When different concentrations of LL-37 treatment were evaluated, $0.05 \mu \mathrm{g} / \mathrm{ml}$ LL-37 resulted in a significant increase in YB-1 mRNA expression $(\mathrm{P}<0.05$; Fig. 3C).

Effect of LL-37 on YB-1 protein expression in SCC cells. Western blot analysis indicated that treatment with LL-37 for $24 \mathrm{~h}$ and at a concentration of $0.5 \mu \mathrm{g} / \mathrm{ml}$ significantly increased the protein expression of YB-1 compared with the controls $(\mathrm{P}<0.05$; Fig. 4A and $\mathrm{B})$. Furthermore, stimulating A431 cells with various concentrations of LL-37 $(0.05,0.5$ or $5 \mu \mathrm{g} / \mathrm{ml}$ ) increased the fluorescence intensity of YB-1 immunostaining, and $0.5 \mu \mathrm{g} / \mathrm{ml} \mathrm{LL}-37$ was observed to cause the greatest increase (Fig. 4C). These results suggested that LL-37 promoted the expression of YB-1 protein in A431 cells.

Analysis of LL-37 signaling in SCC cells. In order to investigate the signaling pathway of LL-37 that induced the expression of YB-1, inhibition experiments were performed. A431 cells were pre-treated with the MEK inhibitor, PD98059, the p38/MAPK inhibitor, SB203580, and the NF- $\mathrm{B}$ inhibitor, PDTC. Treatment with PDTC significantly inhibited the LL-37-induced expression of YB-1 in the A431 cells $(\mathrm{P}<0.05$; Fig. 4D). This indicated that the increased expression of YB-1 by treatment with LL-37 involved the NF- $\kappa$ B signaling pathway.

\section{Discussion}

The results of the current study indicated that YB-1 was weakly expressed in the basal layer of normal skin tissue and strongly expressed in SCC tissue. Treatment with $0.5 \mu \mathrm{g} / \mathrm{ml}$ LL-37 promoted A431 cell viability and invasion, and increased 

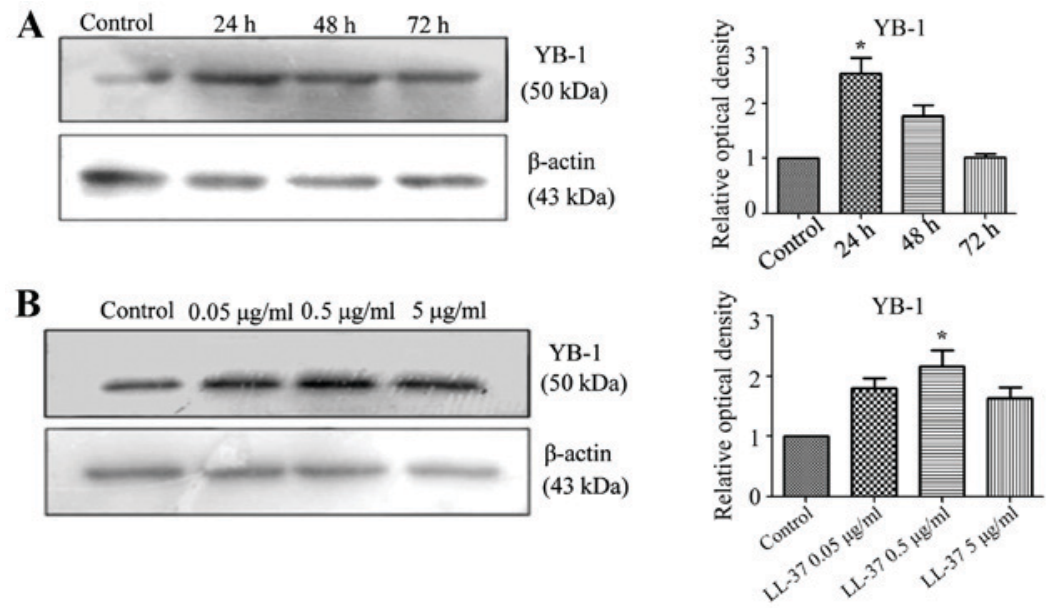

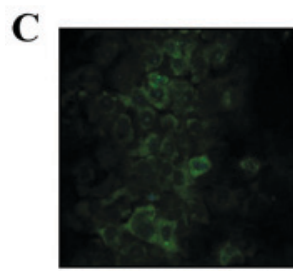

Control

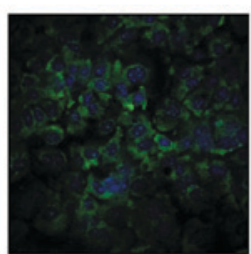

LL-37 $0.05 \mu \mathrm{g} / \mathrm{ml}$

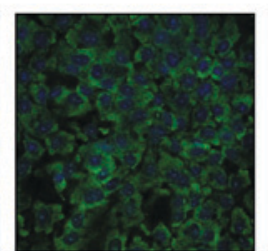

LL-37 $0.5 \mu \mathrm{g} / \mathrm{m}$

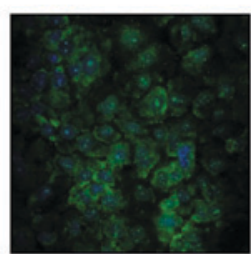

LL-37 $5 \mu \mathrm{g} / \mathrm{ml}$
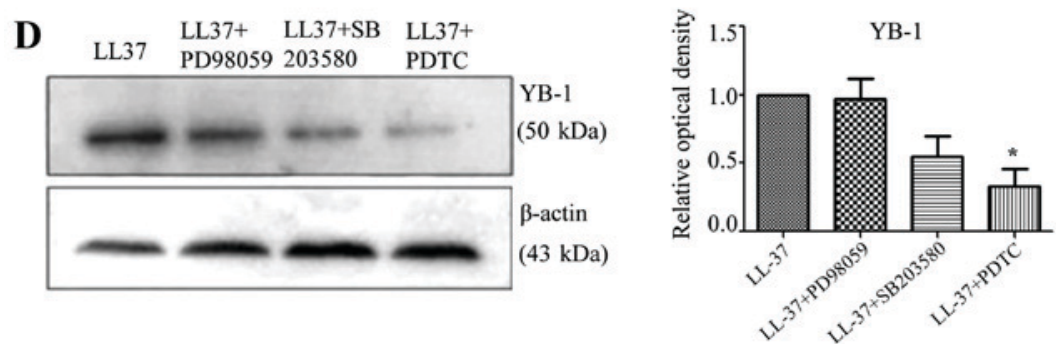

Figure 4. Effect of LL-37 treatment and signaling pathway inhibitors on YB-1 protein expression. (A) Effect of $0.05 \mu \mathrm{g} / \mathrm{ml} \mathrm{LL}-37$ treatment for $0,24,48$ or $72 \mathrm{~h}$ on YB-1 protein expression in A431 cells. YB-1 protein levels were determined by western blot analysis. YB-1 protein was measured relative to $\beta$-actin protein. (B) Effect of LL-37 treatment $(0,0.05,0.5$ or $5 \mu \mathrm{g} / \mathrm{ml})$ for $48 \mathrm{~h}$ on YB-1 protein expression in A431 cells. YB-1 protein levels were determined by western blot analysis. YB-1 protein was measured relative to $\beta$-actin protein. (C) Immunofluorescence assay to evaluate the effect of LL-37 on YB-1 protein levels in A431 cells. A431 cells were stimulated with LL-37 (0, 0.05, 0.5 or $5 \mu \mathrm{g} / \mathrm{ml})$ for $48 \mathrm{~h}$. Magnification, x400. (D) Effect of signaling pathway inhibitors on LL-37-induced YB-1 protein expression. A431 cells were pre-treated for 30 min with mitogen-activated protein kinase kinase inhibitor (PD98059, $10 \mu \mathrm{M})$, mitogen-activated protein kinase inhibitor (SB203580, $10 \mu \mathrm{M}$ ) or nuclear factor- $\kappa \mathrm{B}$ inhibitor (PDTC, $1 \mu \mathrm{M})$, followed by treatment with $0.5 \mu \mathrm{g} / \mathrm{ml}$ of LL-37 for 48 h. YB-1 protein levels were determined by western blot analysis. YB-1 protein was measured relative to $\beta$-actin protein. ${ }^{*} \mathrm{P}<0.05$ vs. control. YB-1, Y-box binding protein 1; PDTC, ammonium pyrrolidinedithiocarbamate.

YB-1 mRNA and protein expression. Inhibiting the NF- $\kappa \mathrm{B}$ signaling pathway led to a decrease in LL-37-induced YB-1 protein expression. This suggested that LL-37 could regulate YB-1 expression, and that this process occurred via the $\mathrm{NF}-\kappa \mathrm{B}$ signaling pathway in A431 cells.

LL-37 is a member of the antibacterial peptide family and is correlated with the proliferation of epidermal cells $(13,14)$. Previous studies have indicated that LL-37 promoted the growth of malignant tumours, primarily via upregulation of EGFR and the epidermal growth factor receptor 2 (ErbB2), in numerous cancer types, such as lung cancer, melanoma, prostate cancer, ovarian cancer and oral SCC (23). Through the induction of membrane-associated protein kinase, EGFR receptors split the metal protein kinase, and LL-37 activates the EGFR, to depend on G-protein coupled receptors (GPCRs) in different tumour cell types, such as lung, prostate and ovarian tumour cells (14,22-24). LL-37 promotes the proliferation and invasion of tumour cells in lung SCC and activates the mitogenic effect of EGFR phosphorylation and the subsequent rat sarcoma (Ras)/MAPK cascade (21). EGFR signaling serves a key function in proliferation, angiogenesis, anti-apoptosis, invasion and metastasis in lung cancer cells $(14,21)$. EGFR ligands, such as transforming growth factor- $\alpha$ and heparin binding epidermal growth factor, are released from the cells after splitting by a protease. These precursors can diffuse freely and activate the EGFR $(26,27)$. Thus, the oncogenic effect of LL-37 is via an EGFR-mediated transcriptional mechanism in some tumour tissues, including lung, prostate and ovarian tumour tissues $(23,26,27)$.

LL-37 has been reported to increase tumour progression via the ErbB-mediated pathway way in breast cancer, and upregulate the expression of ErbB2 or EGFR to promote growth and metastasis (19). FPR2 may also be involved in this process. The activation of MAPK and Janus kinase/signal transducer is the result of a biochemical cascade that involves transcription factor signaling. Previous results indicate that numerous transcription factors lead to significant MAPK and Janus kinase/signal transducer activation and this is 
dependent on FPR2 $(22,24,28)$. In ovarian cancer, LL-37 has previously been reported to stimulate cell proliferation independent of GPCRs (20). However, LL-37 has also been demonstrated to enhance the invasiveness of ovarian cancer cells via upregulation of tissue remodeling enzymes, such as matrix metalloproteinase-2 (MMP-2), a process which is mediated by GPCRs (23). In ovarian cancer cells, FPR2 has previously been reported to increase the expression of MMP-2, thus blocking the GPCRs and promoting the invasiveness of tumour cells $(20,23,26,27)$.

Previous studies have indicated that YB-1 could regulate the proliferation of epithelial cells and is abnormally expressed in prostate cancer, lung cancer and other tumor types (29-32). In transgenic mice, the addition of FPR2 has been reported to increase YB-1 mRNA levels $(11,33)$. Previous results have also suggested that Y-box proteins are involved in the regulation of EGFR and ErbB2 expression, via binding to the enhancer sequences of EGFR and the promoter region of ErbB2 $(6,8)$. This suggests that EGFR and ErbB2 are related to the proliferation and invasion of epidermal tumours.

Furthermore, a previous study demonstrated that the upregulation of YB-1 during cell proliferation is due to upregulation of extracellular signal-regulated kinase 2 (ERK2) and glycogen synthase kinase-3 (GSK-3 $\beta$ ) activity. ERK2 and GSK-3 $\beta$ serve key functions in cell proliferation and apoptosis. Therefore, YB-1 is a downstream target of ERK2 and GSK-3 $\beta$ that promotes cell proliferation and transformation $(10,34)$.

The results of the current study suggested that the expression of YB-1 is increased in SCC. A431 cells were transfected with YB-1 siRNA in order to inhibit the expression of YB-1, and in vitro MTT and Transwell invasion assays confirmed that a reduction of YB-1 reduced their viability and invasion rate. Treatment with $0.5 \mu \mathrm{g} / \mathrm{ml}$ LL-37 increased YB-1 mRNA expression in A431 cells. Immunofluorescence and western blot analyses confirmed that LL-37 treatment also increased YB-1 protein expression changes in A431 cells. Previous studies have reported that LL-37 caused an increase in the degree of malignancy of tumour cells and this process was related to the NF- $\mathrm{NB}$ pathway and the Ras/MAPK signaling cascade $(12,14)$. In the current study, LL-37-treated cells were also treated with MEK, MAPK and NF- $\mathrm{B}$ signaling pathway inhibitors. It was found that YB-1 protein expression, which was increased by LL-37, could be reduced by the NF- $\kappa \mathrm{B}$ inhibitor. This result indicated that LL-37 upregulated YB-1 expression via the $N F-\kappa B$ signaling pathway. $N F-\kappa B$ is a transcription factor that is known to regulate the expression of multiple genes and is involved in a range of cellular responses. LL-37 has previously been reported to increase the levels of $\mathrm{NF}-\kappa \mathrm{B}$ p65 in some tumour cells, such as lung, ovarian and breast cancer cells, which can regulate the expression of genes to promote cell growth. The activation of NF- $\mathrm{BB}$ serves a key function in promoting metastasis and preventing the apoptosis mechanism of tumour cells (35-38). The current study demonstrated that the upregulation of YB-1, induced by LL37, involves the $\mathrm{NF}-\kappa \mathrm{B}$ signaling pathway in A431 cells.

In conclusion, the current study confirms that YB-1 expression is increased in SCC. LL-37 upregulates YB-1 expression and promotes the viability and invasion rate of A431 cells. It is suggested that the activity of LL-37 involves the NF- $\mathrm{B}$ signaling pathway. These results introduce a novel mechanism of LL-37 in tumour occurrence and growth, and may be relevant in developing a new strategy for the clinical treatment of SCC.

\section{Acknowledgements}

The present study was supported by the National Natural Science Foundation of China (grant nos. 81071299, 81371732 and 81573055 ) and was partially supported by the Fundamental Research Funds for the Central Universities and for Changjiang Scholars and Innovative Research Team in University (grant no. PCSIRT:1171).

\section{References}

1. Knackstedt TJ, Brennick JB, Perry AE, Li Z, Quatrano NA and Samie FH: Frequency of squamous cell carcinoma (SCC) invasion in transected SCC in situ referred for Mohs surgery: The dartmouth-hitchcock experience. Int J Dermatol 54: 830-833, 2015.

2. Rogers HW, Weinstock MA, Feldman SR and Coldiron BM: Incidence estimate of nonmelanoma skin cancer (keratinocyte carcinomas) in the US population, 2012. JAMA Dermatol 151: 1081-1086, 2015

3. Sapijaszko M, Zloty D, Bourcier M, Poulin Y, Janiszewski P and Ashkenas J; Canadian Non-melanoma Skin Cancer Guidelines Committee: Non-melanoma skin cancer in canada chapter 5: Management of squamous cell carcinoma. J Cutan Med Surg 19: 249-259, 2015.

4. Sakura H, Maekawa T, Imamoto F, Yasuda K and Ishii S: Two human genes isolated by a novel method encode DNA-binding proteins containing a common region of homology. Gene 73: 499-507, 1988.

5. Eliseeva IA, Kim ER, Guryanov SG, Ovchinnikov LP and Lyabin DN: Y-box-binding protein 1 (YB-1) and its functions Biochemistry (Mosc) 76: 1402-1433, 2011.

6. Shiota M, Izumi H, Onitsuka T, Miyamoto N, Kashiwagi E, Kidani A, Yokomizo A, Naito S and Kohno K: Twist promotes tumor cell growth through YB-1 expression. Cancer Res 68: 98-105, 2008

7. Lasham A, Samuel W, Cao H, Patel R, Mehta R, Stern JL, Reid G, Woolley AG, Miller LD, Black MA, et al: YB-1, the E2F pathway, and regulation of tumor cell growth. J Natl Cancer Inst 104: 133-146, 2012.

8. Lasham A, Print CG, Woolley AG, Dunn SE and Braithwaite AW: YB-1: Oncoprotein, prognostic marker and therapeutic target? Biochem J 449: 11-23, 2013.

9. Takahashi M, Shimajiri S, Izumi H, Hirano G, Kashiwagi E, Yasuniwa Y, Wu Y, Han B, Akiyama M, Nishizawa S, et al: Y-box binding protein-1 is a novel molecular target for tumor vessels. Cancer Sci 101: 1367-1373, 2010.

10. Stratford AL, Habibi G, Astanehe A, Jiang H, Hu K, Park E, Shadeo A, Buys TP, Lam W, Pugh T, et al: Epidermal growth factor receptor (EGFR) is transcriptionally induced by the Y-box binding protein-1 (YB-1) and can be inhibited with Iressa in basal-like breast cancer, providing a potential target for therapy. Breast Cancer Res 9: R61, 2007.

11. Schittek B, Psenner K, Sauer B, Meier F, Iftner T and Garbe C: The increased expression of $\mathrm{Y}$ box-binding protein 1 in melanoma stimulates proliferation and tumor invasion, antagonizes apoptosis and enhances chemoresistance. Int J Cancer 120: 2110-2118, 2007.

12. Durr UH, Sudheendra US and Ramamoorthy A: LL-37, the only human member of the cathelicidin family of antimicrobial peptides. Biochim Biophys Acta 1758: 1408-1425, 2006.

13. Bucki R, Leszczyńska K, Namiot A and Sokolowski W: Cathelicidin LL-37: A multitask antimicrobial peptide. Arch Immunol Ther Exp (Warsz) 58: 15-25, 2010.

14. Wu WK, Wang G, Coffelt SB, Betancourt AM, Lee CW, Fan D, Wu K, Yu J, Sung JJ and Cho CH: Emerging roles of the host defense peptide LL-37 in human cancer and its potential therapeutic applications. Int J Cancer 127: 1741-1747, 2010.

15. Coffelt SB and Scandurro AB: Tumors sound the alarmin(s). Cancer Res 68: 6482-6485, 2008. 
16. Hensel JA, Chanda D, Kumar S, Sawant A, Grizzle WE, Siegal GP and Ponnazhagan S: LL-37 as a therapeutic target for late stage prostate cancer. Prostate 71: 659-670, 2011.

17. Gill K, Mohanti BK, Singh AK, Mishra B and Dey S: The over expression of cathelicidin peptide LL37 in head and neck squamous cell carcinoma: The peptide marker for the prognosis of cancer. Cancer Biomark 10: 125-134, 2011.

18. Kim JE, Kim HJ, Choi JM, Lee KH, Kim TY, Cho BK, Jung JY, Chung KY, Cho D and Park HJ: The antimicrobial peptide human cationic antimicrobial protein-18/cathelicidin LL-37 as a putative growth factor for malignant melanoma. Br J Dermatol 163: 959-967, 2010

19. Heilborn JD, Nilsson MF, Jimenez CI, Sandstedt B, Borregaard N Tham E, Sørensen OE, Weber G and Ståhle M: Antimicrobial protein hCAP18/LL-37 is highly expressed in breast cancer and is a putative growth factor for epithelial cells. Int J Cancer 114: 713-719, 2005 .

20. Coffelt SB, Waterman RS, Florez L, Höner zu Bentrup K, Zwezdaryk KJ, Tomchuck SL, LaMarca HL, Danka ES, Morris CA and Scandurro AB: Ovarian cancers overexpress the antimicrobial protein hCAP-18 and its derivative LL-37 increases ovarian cancer cell proliferation and invasion. Int J Cancer 122 1030-1039, 2008.

21. von Haussen J, Koczulla R, Shaykhiev R, Herr C, Pinkenburg O, Reimer D, Wiewrodt R, Biesterfeld S, Aigner A, Czubayko F and Bals R: The host defence peptide LL-37/hCAP-18 is a growth factor for lung cancer cells. Lung Cancer 59: 12-23, 2008.

22. Coffelt SB, Tomchuck SL, Zwezdaryk KJ, Danka ES and Scandurro AB: Leucine leucine-37 uses formyl peptide receptor-like 1 to activate signal transduction pathways, stimulate oncogenic gene expression, and enhance the invasiveness of ovarian cancer cells. Mol Cancer Res 7: 907-915, 2009.

23. Coffelt SB, Marini FC, Watson K, Zwezdaryk KJ, Dembinski JL, LaMarca HL, Tomchuck SL, Honer zu Bentrup K, Danka ES, Henkle SL and Scandurro AB: The pro-inflammatory peptide LL-37 promotes ovarian tumor progression through recruitment of multipotent mesenchymal stromal cells. Proc Natl Acad Sci USA 106: 3806-3811, 2009.

24. Girnita A, Zheng H, Grönberg A, Girnita L and Ståhle M: Identification of the cathelicidin peptide LL-37 as agonist for the type I insulin-like growth factor receptor. Oncogene 31: 352-365, 2012.

25. Livak KJ and Schmittgen TD: Analysis of relative gene expression data using real-time quantitative PCR and the 2(-Delta Delta C(T)) Method. Methods 25: 402-408, 2001.

26. Chuang CM, Monie A, Wu A, Mao CP and Hung CF: Treatment with LL-37 peptide enhances antitumor effects induced by $\mathrm{CpG}$ oligodeoxynucleotides against ovarian cancer. Hum Gene Ther 20: 303-313, 2009.

27. Li D, Wang X, Wu JL, Quan WQ, Ma L, Yang F, Wu KY and Wan HY: Tumor-produced versican V1 enhances hCAP18/LL-37 expression in macrophages through activation of TLR 2 and vitamin D3 signaling to promote ovarian cancer progression in vitro. PLoS One 8: e56616, 2013.
28. Kittaka M, Shiba H, Kajiya M, Ouhara K, Takeda K, Kanbara K, Fujita T, Kawaguchi H, Komatsuzawa $\mathrm{H}$ and Kurihara $\mathrm{H}$ : Antimicrobial peptide LL37 promotes vascular endothelial growth factor-A expression in human periodontal ligament cells J Periodontal Res 48: 228-234, 2013.

29. Yasen M, Kajino K, Kano S, Tobita H, Yamamoto J, Uchiumi T, Kon S, Maeda M, Obulhasim G, Arii S and Hino O: The up-regulation of Y-box binding proteins (DNA binding protein A and Y-box binding protein-1) as prognostic markers of hepatocellular carcinoma. Clin Cancer Res 11: 7354-7361, 2005.

30. Zhang LL, He DL, Li X, Li L, Zhu GD, Zhang D and Wang XY: Overexpression of coxsackie and adenovirus receptor inhibit growth of human bladder cancer cell in vitro and in vivo. Acta Pharmacol Sin 28: 895-900, 2007.

31. Guay D, Garand C, Reddy S, Schmutte C and Lebel M: The human endonuclease III enzyme is a relevant target to potentiate cisplatin cytotoxicity in Y-box-binding protein-1 overexpressing tumor cells. Cancer Sci 99: 762-769, 2008.

32. Shiota M, Yokomizo A, Tada Y, Uchiumi T, Inokuchi J, Tatsugami K, Kuroiwa K, Yamamoto K, Seki N and Naito S: P300/CBP-associated factor regulates Y-box binding protein-1 expression and promotes cancer cell growth, cancer invasion and drug resistance. Cancer Sci 101: 1797-1806, 2010.

33. Koike K, Uchiumi T, Ohga T, Toh S, Wada M, Kohno K and Kuwano M: Nuclear translocation of the Y-box binding protein by ultraviolet irradiation. FEBS Lett 417: 390-394, 1997.

34. Oda Y, Ohishi Y, Basaki Y, Kobayashi H, Hirakawa T, Wake N, Ono M, Nishio K, Kuwano M and Tsuneyoshi M: Prognostic implications of the nuclear localization of Y-box-binding protein-1 and CXCR4 expression in ovarian cancer: Their correlation with activated Akt, LRP/MVP and P-glycoprotein expression. Cancer Sci 98: 1020-1026, 2007.

35. Sasaki Y and Iwai K: Roles of the NF-kB pathway in B-lymphocyte biology. Curr Top Microbiol Immunol 393: 177-209, 2016.

36. Huang L, Liu Q, Zhang L, Zhang Q, Hu L, Li C, Wang S, Li J, Zhang $\mathrm{Y}, \mathrm{Yu} \mathrm{H}$, et al: Encephalomyocarditis virus $3 \mathrm{C}$ protease relieves TRAF family member-associated NF- $\kappa B$ activator (TANK) inhibitory effect on TRAF6-mediated NF- $\kappa$ B signaling through cleavage of TANK. J Biol Chem 290: 27618-27632, 2015.

37. Quaglio AE, Castilho AC and Di Stasi LC: Experimental evidence of heparanase, Hsp70 and NF- $\mathrm{BB}$ gene expression on the response of anti-inflammatory drugs in TNBS-induced colonic inflammation. Life Sci 141: 179-187, 2015.

38. Tomás A, Lery L, Regueiro V, Pérez-Gutiérrez C, Martínez V, Moranta D, Llobet E, González-Nicolau M, Insua JL, Tomas JM, et al: Functional genomic screen identifies klebsiella pneumoniae factors implicated in blocking nuclear factor $\kappa \mathrm{B}$ (NF-кB) signaling. J Biol Chem 290: 16678-16697, 2015. 